\title{
Influence of equation used to estimate the renal function in dosage potentially nephrotoxic drug
}

\author{
Aurelio Cabello-Muriel, ${ }^{1}$ Elena Urbieta-Sanz, ${ }^{2}$ Carles Iniesta-Navalón, ${ }^{2}$ \\ Juan B Cabezuelo-Romero, ${ }^{3}$ Juan José Gascón-Cánovas ${ }^{4}$
}

${ }^{1}$ Pharmacy Department, Hospital de Torrevieja, Torrevieja, Spain ${ }^{2}$ Pharmacy Department, Hospital General Universitario Reina Sofía de Murcia, Murcia, Spain

${ }^{3}$ Nephrology Department, Hospital General Universitario Reina Sofía de Murcia, Murcia, Spain

${ }^{4}$ The Public Health Department, University of Murcia, Murcia, Spain

\section{Correspondence to} Dr Aurelio Cabello Muriel, Pharmacy Department, Hospital de Torrevieja, cv-95 sn, Torrevieja, Alicante 03186, Spain;

aurelio_cabello@yahoo.es

Received 31 March 2014 Revised 12 June 2014 Accepted 30 June 2014 Published Online First 17 July 2014

\section{ABSTRACT \\ Objective To evaluate the similarity (or not) of the} dose recommendations according to the Cockcroft-Gault and MDRD4 (modified diet in renal disease) equations. Method A cross-sectional comparative observational test of patients suffering chronic renal illness that involved treatment using nephrotoxic drugs, admitted consecutively to the internal medicine department over a period of 6 months. The glomerular filtrate rate was calculated upon admission and at discharge using the Cockcroft-Gault and MDRD4 formulas. Grading of the disease for patients and dose adjustment recommendations of potentially nephrotoxic drugs was compared. The degree of correlation between the results obtained with both equations was assessed by means of the Pearson's coefficient $(r)$, considering $p<0.05$ as significant.

Results Among the 249 patients included in the study, the staging of the disease was modified in 166 and the recommended dosage would have differed in $56.0 \%$ of these. Of the 222 prescriptions of potentially nephrotoxic drugs, 145 dosage adjustment recommendations would have differed. Glomerular filtrate rates were always less when the Cockcroft-Gault equation was used, although they were closely correlated both upon admission and discharge (Pearson's $r=0.83$ and 0.81 , respectively, $\mathrm{p}<0.001)$.

Conclusions Although the Cockcroft-Gault and MDRD4 equations were statistically well correlated, differences in drug dose recommendations were noticeable.

\section{INTRODUCTION}

Chronic kidney disease (CKD) is a common disorder, in which a slow loss of renal function occurs with time. Of the Spanish population, $11 \%$ is thought to suffer some degree of renal insufficiency. ${ }^{1}$ Traditionally, serum creatinine concentrations have been used for diagnosis of the disease, but in some patients, especially in older patients, even those whose serum creatinine is within a normal range, kidney function is already impaired and so has standardised estimate the glomerular filtration rate (GFR) by equations that use serum creatinine and some demographic and anthropometric variables.

Estimating the GFR from serum creatinine concentrations by equations is recommended by $\mathrm{K} /$ DOQI and KDIGO guidelines in clinical practice, although the reference method is to measure the renal clearance of exogenous substances such as inulin, but this requires conditions that are not generally available. ${ }^{2}$ However, depending on the equation used, the results tend to differ widely. ${ }^{3}$
Much has been written on what the best method is to estimate the degree of GFR to evaluate the renal function of patients, especially those suffering from CKD. ${ }^{1-7}$ Since 2000, when the MDRD4 (modified diet in renal disease) formula was first published, many authors have attempted to compare it with the Cockcroft-Gault (CG) formula, ${ }^{4-8}$ which was the method of choice. Although other, less commonly used equations, such as CKD-EPI and Jelliffe ${ }^{45}$ have also been compared, the MDRD4 formula is recommended by the National Kidney Foundation ${ }^{9}$ to estimate the GFR and establish the state of CKD. However, in common practice, most recommendations for drug dose adjustment are based on the CG equation. $^{10}$

The CG equation was published in 1976 and has been routinely used for the dose adjustment of drugs. While it was developed to estimate creatinine clearance from a population of 236 individuals older than 18 years (18-92), 96\% of the subjects were over 65 , mostly male and had a mean creatinine clearance of $72.7 \mathrm{~mL} / \mathrm{min}$. The variables required for the calculation are age, height, sex and serum creatinine. The MDRD4 equation is the result of a retrospective study 'Modification of diet in renal disease', which was developed in a population of 1070 adult individuals with CKD, of both sexes, who presented a mean value of $40 \mathrm{~mL} / \mathrm{min} /$ $1.73 \mathrm{~m}^{2}$.

Among the patients included in the study of CG formula, 96\% were elderly while in the study of Levey et al to MDRD4 formula, most of the individuals were under 55. In addition, individuals included in the MDRD4 study had further deterioration of renal function than those who were included in CG study.

Mathematical description of equations for estimating glomerular filtration is shown in table 1 .

There seems to be a general agreement that MDRD4 is more precise than $\mathrm{CG}^{7}$ since it estimates GFR directly and not through creatinine clearance so that its use is recommended for patient diagnosis and staging. However, CG continues to be recommended for adjusting the dose of nephrotoxic drugs since this is the formula used in assays to evaluate these drugs and upon which recommendations are based. On the other hand, MDRD4 does not require the patient's weight to be known (not always easy in a hospital environment) and this, too, contributes to it being more widely used than CG to adjust drug doses.

Given the paucity of studies on the influence of any variation in the outcome of using these equations, the aim of this study was to ascertain whether or not the equations are interchangeable 
Table 1 Mathematical description of equations for estimating glomerular filtration

\begin{tabular}{ll}
\hline MDRD4 & $\begin{array}{l}\text { Estimated GFR }=186 \times(\text { creatinine })^{-1.154} \times(\text { age })^{-0.203} \times(0.742 \text { if } \\
\text { female }) \times(1.210 \text { if black })\end{array}$ \\
Cockcroft- & Estimated creatinine clearance $=((140-$ age $) \times$ weight/ \\
Gault & $72 \times($ creatinine $)) \times(0.85$ if female $)$
\end{tabular}

GFR, glomerular filtration rate; MDRD, modified diet in renal disease.

in common clinical practice for dose adjustment purposes in patients suffering from CKD. We therefore evaluated the extent of any coincidence in estimating GFR using CG and MDRD4 in hospitalised patients with CKD to determine to what extent the dosification of potentially nephrotoxic drugs may be affected.

\section{MATERIALS AND METHODS}

The cross-sectional comparative observational test was carried out in the internal medicine (IM) department of an important hospital with 330 beds, of which $33 \%$ are designated for use by the said service. The test included IM patients over the age of 18 suffering from CKD, defined as the presence of a GFR (estimated by the CG equation) of below $60 \mathrm{~mL} / \mathrm{min} / 1.73 \mathrm{~m}^{2}$ during the previous 3 months and who were taking a potentially nephrotoxic drug. Exclusion criteria were a clinical situation in which GFR estimation could not be made by a suitable equation: for example, patients following a strictly vegetarian diet or taking creatinine supplements; individuals with important alterations in muscle mass due to amputations, muscular diseases or paralysis; those with a muscle mass below $19 \mathrm{~kg} / \mathrm{m}^{2}$ or above $35 \mathrm{~kg} / \mathrm{m}^{2}$; the presence of severe liver disease, generalised oedema or ascitis; and pregnant women. ${ }^{7}$ The recruitment period ran from November 2012 to May 2013.

A drug is considered as potentially nephrotoxic when the prospectus mentions any adverse effect it might have on the kidneys, regardless of the aetiology of the same or the frequency with which it appears, requiring also the dose to be adjusted in cases of renal illness.

The GFR was calculated upon admission and discharge for all the patients included in the study based on their creatinine concentrations, using for this purpose the classic CG formula (after ascertaining the weight of each subject) and the MDRD4 equation. As in the case for inclusion, the GFR estimated by CG was used to establish renal disease staging according to the classification of the National Kidney Foundation and the most up-to-date version of the National Institute of Health and Care Excellence (NICE) guide. ${ }^{9} 10$

Table 2 Prevalence of patients in each stage upon admission using each equation according to the most recent modification of the K/DOQI guidelines for CKD classification

\begin{tabular}{lll}
\hline & $\begin{array}{l}\text { No. of patients } \\
\text { using CG }\end{array}$ & $\begin{array}{l}\text { No. of patients } \\
\text { using MDRD4 }\end{array}$ \\
\hline Stages 1-2 & 0 & 56 \\
Stage 3 & \\
3A (GFR 45-59) & 43 & 70 \\
3B (GFR 30-44) & 109 & 78 \\
Stage 4 (GFR 15-29) & 85 & 41 \\
Stage 5 (GFR <15) & 12 & 4 \\
\hline CKD, chronic kidney disease; CG, Cockcroft-Gault; GFR, glomerular filtration rate; \\
MDRD4, modified diet in renal disease.
\end{tabular}

The complete pharmacological treatment of each patient was recorded, identifying potentially nephrotoxic drugs and any recommendations of dose adjustment. Hospital treatment was obtained by application of the computerised SAVAC system. Home treatment, clinical and demographic data were obtained from the computerised medical history of each patient. To verify any home treatment, a structured interview was conducted for each patient or carer using a normalised questionnaire in which the following details were recorded: commercial name of drug, active ingredient, dose, frequency, route of administration and duration of treatment.

To identify potentially nephrotoxic drugs with recommended dose adjustment, a dosage guide for 109 drugs used in renal insufficiency previously drawn up by pharmacists and nephrologists at the hospital was consulted. ${ }^{11}$ This guide was based on an exhaustive review of the available literature and on the recommendations made in the main related documents. ${ }^{12-16}$ The stages mentioned in the guide were those of the classification published by the National Kidney Foundation in 2002. ${ }^{9}$

The prevalence of each CKD stage was recorded at admission using both formulas, noting in how many patients a change would have been recommended and which drugs would have been affected.

A descriptive statistical analysis was made of the demographic and clinical variables of interest, calculating the mean and SD of the GFR obtained by CG and MDRD4 for the whole group and according to each CKD stage. To permit comparisons, the GFR data obtained by CG were normalised for a body area of $1.73 \mathrm{~m}^{2}$ since MDRD4 estimates are already corrected to this body area. The relative differences in clearance were estimated taking as reference the GFR calculated by the CG equation.

Finally, to check the degree of correlation between the results obtained by both equations' a Pearson's correlation index (r) was used, considering as significant $p<0.05$. The extent of agreement or common variability was calculated by the coefficient of determination $\mathrm{r}^{2}$.

\section{RESULTS}

Of the 249 patients, $52.6 \%$ were women. The mean age was 81.8 years (74-90), mean height $1.63 \mathrm{~m} \mathrm{(1.40-1.86)}$ and weight $73.2 \mathrm{~kg}(59-87)$. The mean length of time in hospital was $12.0 \pm 8.1$ days. Ninety-eight per cent of the patients were considered polymedicated, taking more than five different medicines per day during their stay. The main reasons for admission were cardiac or respiratory-related pathologies. According to the pluripathology criteria of the Andalusian Department of Health, ${ }^{17} 63.3 \%$ of the patients could be regarded as such, the main pathologies, besides CKD, being auricular fibrillation, type II diabetes mellitus, high blood pressure and hyperlipidaemia. Upon admission, the mean number of drugs per patient was $12.9 \pm 2.0$, of which $1.5 \pm 0.6$ were potentially nephrotoxic.

Patient staging closely depended on the equation used, as can be seen in table 2 . Indeed, the stage of the disease varied with the equation used in 166 of the patients included in the study (66.7\%). In 93 cases (56.0\%), dose adjustment recommendation of at least one potentially nephrotoxic drug would be modified. Of the 222 prescriptions of potentially nephrotoxic drugs, dose adjustment would be modified in 145 depending on the equation used. The drugs whose recommended doses varied are shown in table 3.

Mean GFR upon admission and discharge was always 20$50 \%$ lower with the CG formula adjusted for body area than 
Table 3 Recommendations using the CG formula compared with those that would have been made using the MDRD4 formula

\begin{tabular}{|c|c|c|c|}
\hline Drug & $\begin{array}{l}\text { Recommendation } \\
\text { with GFR calculated } \\
\text { by CG }\end{array}$ & $\begin{array}{l}\text { Recommendation } \\
\text { with GFR calculated } \\
\text { by MDRD4 }\end{array}$ & $\mathbf{n}$ \\
\hline & $200 \mathrm{mg} / 24 \mathrm{~h}$ & $300 \mathrm{mg} / 24 \mathrm{~h}$ & 3 \\
\hline \multirow[t]{2}{*}{ Allopurinol } & $150 \mathrm{mg} / 24 \mathrm{~h}$ & $200 \mathrm{mg} / 24 \mathrm{~h}$ & 14 \\
\hline & $100 \mathrm{mg} / 48 \mathrm{~h}$ & $150 \mathrm{mg} / 24 \mathrm{~h}$ & 2 \\
\hline Amoxycillin/clavulanic & $500 / 12 \mathrm{~h}$ & UD & 8 \\
\hline Amikacin* & $7.5 \mathrm{mg} / \mathrm{kg} / 24 \mathrm{~h}$ & $5 \mathrm{mg} / \mathrm{kg} / 24 \mathrm{~h}$ & 1 \\
\hline Ampicillin & $1-2 \mathrm{~g} / 8 \mathrm{~h}$ & $1-2 \mathrm{~g} / 6 \mathrm{~h}$ & 2 \\
\hline Captopril & $12.5 \mathrm{mg} / 8 \mathrm{~h}$ & UD & 1 \\
\hline Ceftriaxone & $1 \mathrm{~g} / 24 \mathrm{~h}$ & UD & 1 \\
\hline Ciprofloxacin & $200 \mathrm{mg} / 12 \mathrm{~h}$ & UD & 2 \\
\hline \multirow[t]{2}{*}{ Colchicine } & Avoid & $0.5 \mathrm{mg} / 24 \mathrm{~h}$ & 1 \\
\hline & Di: $5-10 \mathrm{mg} / 24 \mathrm{~h}$ & $2.5-20 \mathrm{mg} / 24 \mathrm{~h}$ & 10 \\
\hline \multirow[t]{2}{*}{ Enalapril } & Di: 2.5 mg/24 h & Di: $5-10 \mathrm{mg} / 24 \mathrm{~h}$ & 6 \\
\hline & Di: $2.5 \mathrm{mg} / 24 \mathrm{~h}$ & $2.5-20 \mathrm{mg} / 24 \mathrm{~h}$ & 1 \\
\hline Fenofibrate & $160 \mathrm{mg} / 24 \mathrm{~h}$ & $145-250 \mathrm{mg} / 24 \mathrm{~h}$ & 1 \\
\hline Gentamicin* & $4-5 \mathrm{mg} / \mathrm{kg} / 48 \mathrm{~h}$ & $3.5 \mathrm{mg} / \mathrm{kg} / 24 \mathrm{~h}$ & 1 \\
\hline Hydrochlorothiazide & Avoid & UD & 6 \\
\hline \multirow[t]{3}{*}{ Levofloxacin } & $250 \mathrm{mg} / 24 \mathrm{~h}$ & $500 \mathrm{mg} / 24 \mathrm{~h}$ & 14 \\
\hline & $250 \mathrm{mg} / 48 \mathrm{~h}$ & $250 \mathrm{mg} / 24 \mathrm{~h}$ & 3 \\
\hline & $0.5-1 \mathrm{~g} / 8 \mathrm{~h}$ & $0.5-1 \mathrm{~g} / 6-8 \mathrm{~h}$ & 5 \\
\hline \multirow[t]{2}{*}{ Meropenem } & $0.5-1 \mathrm{~g} / 12 \mathrm{~h}$ & $0.5-1 \mathrm{~g} / 8 \mathrm{~h}$ & 8 \\
\hline & $0.5-1 \mathrm{~g} / 24 \mathrm{~h}$ & $0.5-1 \mathrm{~g} / 12 \mathrm{~h}$ & 1 \\
\hline \multirow[t]{2}{*}{ Piperacillin-Tazobactam } & $3 \mathrm{~g} / 8 \mathrm{~h}$ & $2-4 / 6-8 \mathrm{~h}$ & 5 \\
\hline & $2 \mathrm{~g} / 8 \mathrm{~h}$ & $3 \mathrm{~g} / 8 \mathrm{~h}$ & 2 \\
\hline \multirow[t]{2}{*}{ Ramipril } & $2.5-5 \mathrm{mg} / 24 \mathrm{~h}$ & $5-10 \mathrm{mg} / 24 \mathrm{~h}$ & 5 \\
\hline & $1.25-5 \mathrm{mg} / 24 \mathrm{~h}$ & $2.5-5 \mathrm{mg} / 24 \mathrm{~h}$ & 17 \\
\hline \multirow[t]{2}{*}{ Ranitidine } & $50 \mathrm{mg} / 8 \mathrm{~h}$ & $50 \mathrm{mg} / 6-8 \mathrm{~h}$ & 10 \\
\hline & $50 \mathrm{mg} / 12 \mathrm{~h}$ & $50 \mathrm{mg} / 8 \mathrm{~h}$ & 10 \\
\hline Teicoplanin & $200 \mathrm{mg} / 24 \mathrm{~h}$ & $400 \mathrm{mg} / 24 \mathrm{~h}$ & 2 \\
\hline Tobramycin* & $3.5 \mathrm{mg} / \mathrm{kg} / 24 \mathrm{~h}$ & $4-5 \mathrm{mg} / \mathrm{kg} / 24 \mathrm{~h}$ & 1 \\
\hline \multirow[t]{2}{*}{ Vancomycin* } & $1 \mathrm{~g} / 24 \mathrm{~h}$ & $15-20 \mathrm{mg} / \mathrm{kg} / 24 \mathrm{~h}$ & 1 \\
\hline & $1 \mathrm{~g} / 72 \mathrm{~h}$ & $1 \mathrm{~g} / 24 \mathrm{~h}$ & 1 \\
\hline
\end{tabular}

${ }^{*}$ Monitoring of plasma levels recommended.

CG, Cockcroft-Gault; Di, initial dose; GFR, glomerular filtration rate; MDRD4, modified diet in renal disease; UD, usual dose.

with MDRD4. The increase was particularly pronounced in patients with low clearance values (table 4).

Figure 1 shows the dispersion of the GFR upon admission and at discharge according to the equation used. The GFR values adjusted for body area obtained by CG and MDRD4

Table 4 Differences in mean GFR estimated upon admission and at discharge according to the equation used and CKD stage (reference CG)

\begin{tabular}{|c|c|c|c|c|c|c|}
\hline & \multicolumn{3}{|c|}{$\begin{array}{l}\text { GFR (admission) (mL/min/ } \\
\left.1.73 \mathrm{~m}^{2}\right)\end{array}$} & \multicolumn{3}{|c|}{$\begin{array}{l}\text { GFR (discharge) }(\mathrm{mL} / \mathrm{min} / \\
\left.1.73 \mathrm{~m}^{2}\right)\end{array}$} \\
\hline & $\begin{array}{l}\text { C-G } \\
(\text { mean } \\
\pm \text { SD) }\end{array}$ & $\begin{array}{l}\text { MDRD-4 } \\
\text { (mean } \\
\pm \text { SD) }\end{array}$ & $\%$ Dif & $\begin{array}{l}\text { C-G } \\
(\text { mean } \\
\pm \text { SD) }\end{array}$ & $\begin{array}{l}\text { MDRD } \\
\text { (mean } \\
\pm S D)\end{array}$ & $\%$ Dif \\
\hline General & $32.4 \pm 10.1$ & $46.1 \pm 16.8$ & +42.0 & $42.8 \pm 17.4$ & $54.9 \pm 23.4$ & +28.3 \\
\hline Stage $3(3 \mathrm{~A}, 3 \mathrm{~B})$ & $38.9 \pm 6.53$ & $54.2 \pm 13.7$ & +39.3 & $51.1 \pm 14.5$ & $63.0 \pm 20.9$ & +23.3 \\
\hline Stages 4-5 & $22.2 \pm 5.4$ & $33.4 \pm 12.8$ & +50.4 & $29.8 \pm 13.2$ & $42.4 \pm 21.7$ & +42.3 \\
\hline \multicolumn{7}{|c|}{$\begin{array}{l}\text { CKD stage according to most recent modification of the K/DOQI guidelines for CKD } \\
\text { classification. } \\
\% \text { Dif: Differences between means as a percentage (GFR(CG)-GFR(MDR4)/GFR } \\
(\mathrm{CG}) \times 100) \text {. }\end{array}$} \\
\hline
\end{tabular}

upon admission were highly significantly correlated (Pearson's $\mathrm{r}=0.83, \mathrm{p}<0.001)$. The results were similar for the estimations based on high creatinine concentrations (Pearson's $r=0.81$, $\mathrm{p}<0.001)$. The degree of agreement or common variability between both variables $\left(\mathrm{r}^{2}\right)$ was $68.89 \%$ upon admission and $65.12 \%$ at discharge.

\section{DISCUSSION}

While the results point to a strongly significant correlation between the two equations, it is clear that the use of one or the other surprisingly affects the CKD stage established in $46 \%$ of patients. Indeed, in $22 \%$ of cases, a pathological renal function would not even have been considered (56 patients passed to stage 1-2) if the MDRD4 formula was used. Consequently, the dose recommendations of potentially nephrotoxic drugs would vary considerably in a high number of patients.

Other studies ${ }^{18}$ agree with our results concerning the high degree of correlation between the two equations, although this does not necessarily mean good agreement. The fact that both can detect the greater or lesser degree of CKD and show good linear relation in terms of GFR does not exclude that fact that there are important differences between both methods. The disease was diagnosed as more serious when the CG equation was used than when MDRD4 was used, which agrees with the findings of other authors. 819

However, our study focuses on the consequence of such differences when it comes to the doses of any potentially nephrotoxic drugs prescribed. MDRD4 is the recommended formula for staging by leading scientific societies because of its easy implementation. ${ }^{7}$ But CG is the formula on which adjustment recommendations are based by the manufacturing laboratories. Several authors have mentioned that the recommended dose of a given drug may vary substantially according to the method used and may have clinical consequences, the severity of which will depend on the type of drug. Peral-Aguiiregoitia et al ${ }^{20}$ show in their study how the recommended dose of two highrisk drugs, the anticoagulant dabigatran and the antibiotic daptomycin, varied according to whether CG or MDRD4 was used, and suggested the former should be used for drug adjustment.

In our case, the proportion of recommendations that differed was substantial, as was the number of drugs affected. The most frequently modified recommendations would have been for the ACEIs (ramipril, enalapril), ranitidine, allopurinol and levofloxacin, all renal toxic, which would have been overdoses with potentially serious effects. The importance of this problem increases when the patient is discharged with one or more drug overdoses since prolonged exposure might contribute to severe deterioration of the renal function.

The decision as to which formula is best for evaluating the renal function of patients with CKD is controversial. ${ }^{21}$ In a revision, Coresh and Stevens ${ }^{22}$ concluded that most studies opted for MDRD4, but contrary conclusions have also been reached. ${ }^{23}$ Such variability may be explained by the characteristics of the populations included in the studies. Indeed, it should be noted that substantially different populations were used to obtain both formulas; for example, patients over 70 years of age, diabetics treated with insulin, patients with creatinine concentration in excess of $7 \mathrm{mg} / \mathrm{mL}$ and those with chronic processes were excluded in the case of MDRD4, while $96 \%$ of the patients included in the CG study were elderly men. ${ }^{24} 25$ This lends weight to the suitability of the CG equation for use in our population, given the advanced age of the patients with CKD who were admitted to the IM ward. 

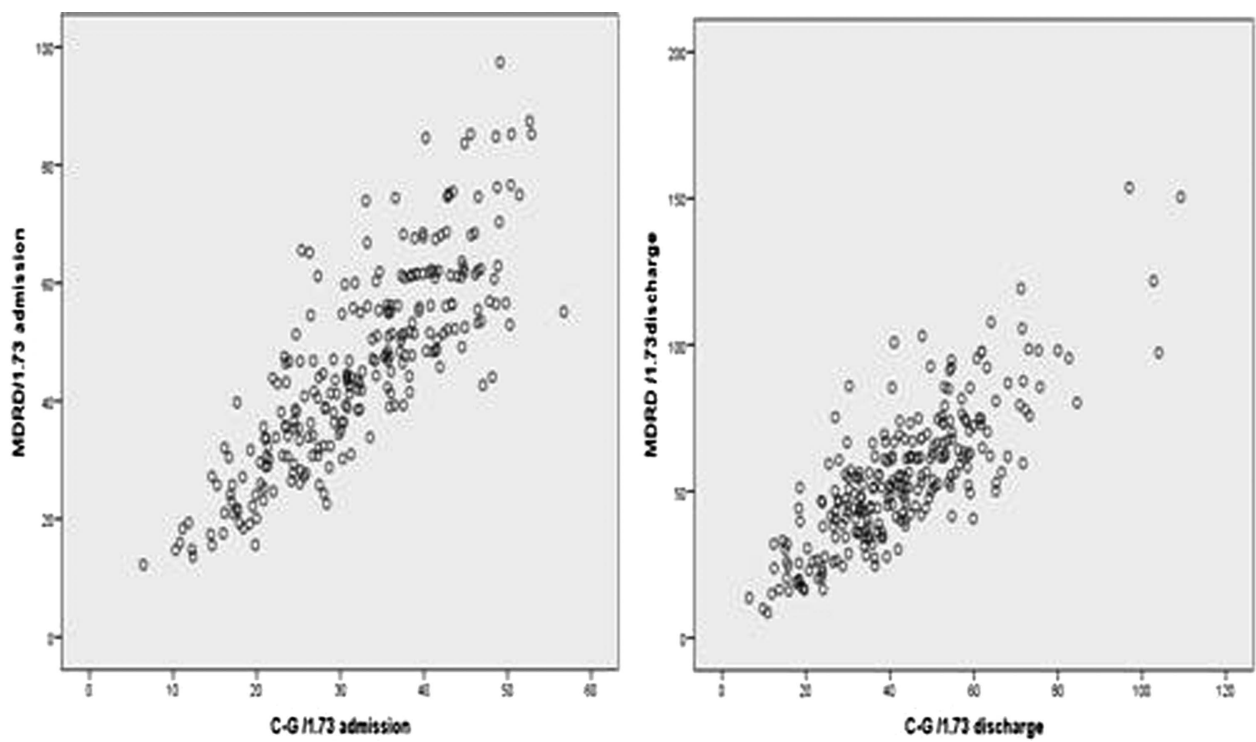

Figure 1 Dispersion diagram of the variables MDRD and CG upon admission and at discharge.

The results underline the danger of overdosification in patients with CKD when the formula used to estimate GFR in clinical practice is not that used for the original dose recommendation. While it might appear that the CG and MDRD4 equations are closely correlated, there are real and substantial differences. In our opinion, the use of either formula has sufficient clinical relevance to enable a move towards a consensus solution that should put an end to the controversy.

\section{Key messages}

What is already known on this subject

- Estimation of renal function by formulas is recommended in most cases in clinical practice.

- There is some variability in the results depending on the formula used to estimate renal function in patients with chronic kidney disease (CKD).

- In patients with CKD, the dose of renal risk drugs should be adjusted according to renal function.

\section{What this study adds}

- Drugs that are mainly affected in recommending dosage adjustment when using the Cockcroft-Gault formula or MDRD4 (modified diet in renal disease).

- How many patients with CKD are affected in recommending dosage adjustment when using the Cockcroft-Gault formula or MDRD4.

Acknowledgements We are grateful to the medical and nursing staff of the internal medicine service of the Reina Sofia hospital for their invaluable help.

Competing interests None.

Patient consent Obtained.

Provenance and peer review Not commissioned; externally peer reviewed.

\section{REFERENCES}

1 Otero A, de Francisco ALM, Gayoso P, et al. Prevalence of chronic renal disease in Spain: Results of the EPIRCE study. Nefrología 2010;30:78-86.

2 Stevens LA, Coresh J, Greene T, et al. Assessing kidney function-Measured and estimated glomerular filtration rate. N Engl J Med 2006;354:2473-83.
3 Vassalotti JA, Tevens LA, Levey AS. Testing for chronic kidney disease: a position statement from the National Kidney Foundation. Am J Kidney Dis 2007; 50:169-80

4 Stevens L, Nolin T, Richardson M, et al. Comparison of drug dosing recommendations based on measured GFR and Kidney function estimating equations. Am J Kidney Dis 2009;54:33-42.

5 Wilhelm S, Kale-Pradman P. Estimating creatinine clearance: a meta-analysis. Pharmacotherapy 2011;31:658-64.

6 Jin R, Grunkemeir G, Brown J, et al. Estimated glomerular filtration rate and renal function. Ann Thorac Surg 2008;86:1-3.

7 Gracia S, Montañés R, Bover J, et al. Documento de consenso: Recomendaciones sobre la utilización de ecuaciones para la estimación del filtrado glomerular en adultos. Nefrología 2006;26:658-64.

8 Roblin I, De Sobaritsky S, Basselin C, et al. Estimated glomerular filtration rate for drug dose adjustment: Cockcroft and Gault or abbreviated MDRD equation? Clinical Biochemistry 2009;42:111-13.

9 National Kidney Foundation. K/DOQI clinical practice guidelines for chronic kidney disease: evaluation, classification, and stratification. Am J Kidney Dis 2002;39: S1-266.

10 Guías NICE. BMJ 2008;337:1530-45.

11 Grupo de trabajo de Farmacia y Nefrología. Guía de dosificación de fármacos en insuficiencia renal. HGU Reina Sofía Murcia. Unidad Técnica de Comunicación, 2012.

12 Dowling TC, Matzke GR, Murphy JE, et al. Evaluation of renal drug dosing: prescribing information and clinical pharmacist approaches. Pharmacotherapy 2010;30:776-86

13 Chertow GM, Lee J, Kuperman GJ, et al. Guided medication dosing for inpatients with renal insufficiency. JAMA 2001;16:369-75.

14 Mensa J, Gatell JM, Garcia-Sanchez JE, et al. Guía de terapéutica antimicrobiana. Antares, 2011.

15 Fichas técnicas de los medicamentos. Agencia Española de Medicamentos y Productos Sanitarios. http://www.aemps.gob.es/cima/fichasTecnicas [Consultado en Junio 2012].

16 David N, Robert C, George M, et al. The Sanford guide to antimicrobial therapy. 41st edn. 2011.

17 Ramirez-Duque N, Ollero-Baturone M, Bernabeu-Wittel M, et al. Características clínicas, funcionales, mentales y sociales de pacientes pluripatológicos. Estudio prospectivo durante un año en Atención Primaria. Rev Clin Esp 2008;208:4-11.

18 VillegasHenao M. Correlación de las ecuaciones para el cálculo de depuración de creatinina en adultos con enfermedad renal crónica no terminal. Medicina UPB27:89-95.

19 Buitrago F, Calvo Jl, Gómez-Jimenez C, et al. Comparación y concordancia de las ecuaciones de estimación de filtrado glomerular de Cockcroft-Gault y MDRD en el diagnóstico de la enfermedad renal crónica oculta. Nefrología 2008; 28:301-10

20 Peral-Aguiiregoitia J, Lertxundi-Etebarria U, Saracho-Rotaeche R, et al. Estimación de la tasa de filtración glomerular para el ajuste posológico de fármacos. Reina la Confusión. Nefrología 2012;32:115-17.

21 Esteve Poblador S, Gorriz S, Ortuño M. Comparación de dos ecuaciones para estimar el filtrado glomerular. Rev Clin Esp 2012;212:75-80. 
22 Coresh J, Stevens LA. Kidney function estimating equations: where do we stand? Curr Opin Nephrol Hypertens 2006;15:276-84

23 Teruel JL, Sabater J, Galeano C, et al. La ecuación de Cockcroft-Gault es preferible a la ecuación MDRD para medir el filtrado glomerular en la insuficiencia renal crónica avanzada. Nefrología 2007;27:313-19.
24 Cockroft DW, Gault MH. Prediction of creatinine clearance from serum creatinine. Nephron 1976;16:31-41.

25 Levey AS, Bosch JP, Lewis JB, et al. A more accurate method to estimate glomerular filtration rate from serum creatinine: a new prediction equation. Modification of Diet in Renal Disease Study Group. Ann Intern Med 1999;130:461-70.

\section{ADVANCING} POSTGRADUATES. ENHANCING HEALTHCARE.

The Postgraduate Medical Journal is dedicated to advancing the understanding of postgraduate medical education and training.

- Acquire the necessary skills to deliver the highest possible standards of patient care

- Develop suitable training programmes for your trainees

- Maintain high standards after training ends

Published on behalf of the Fellowship of Postgraduate Medicine (FPM)

FOR MORE DETAILS OR TO SUBSCRIBE, VISIT pmj.bmj.com 